\title{
Istota zobowiązania wekslowego w prawie polskim, część I
}

\section{The Essence of Liability of Bill of Exchange in Polish Law, part I}

\section{mgr Jakub Abramowicz}

E-mail: jakub.abramowicz2@gmail.com; nr orcid: 0000-0002-0353-998X

\begin{abstract}
Streszczenie
Istota zobowiązania wekslowego była i jest przedmiotem sporu. Dyskusja dotycząca charakteru prawnego weksla trwa po dziś dzień i jak się wydaje nie wypowiedziano w niej jeszcze ostatniego słowa. Do tej pory nie ma w piśmiennictwie zgody co do tego, w której chwili zobowiązanie wekslowe powstaje. Spośród wielości prezentowanych w doktrynie teorii wekslowych, za najistotniejsze z nich należy uznać teorię kreacyjną oraz teorię umowną. Teoria umowna, choć historycznie starsza, zdaje się dominować w obecnym piśmiennictwie i judykaturze. Celem niniejszego opracowania jest usystematyzowanie poglądów doktryny w tym zakresie oraz przedstawienie własnego stanowiska.
\end{abstract}

Słowa kluczowe: weksel, teorie wekslowe, indos, papiery wartościowe, jednostronna czynność prawna.

\section{Summary}

The legal character of a bill of exchange has been a cause of much controversy and dispute in the past, and remains to this day. Debates over its legal character are still very much alive, and it appears that they will be in the future. Even today, there is no agreement on when does the liability of a bill of exchange begin. From the variety of theories presented in the doctrine of a bill of exchange the most prominent ones are the creation theory (unilateral legal action) and the contract theory (bilateral legal action). Contract theory although historically older, appears to dominate in current legal literature and judicatory. The aim of this work is to systematise views on the issue and to present my own position on the issue.

Key words: bill of exchange, bill of exchange theories, endorsement, securities, unilateral legal action.

JEL: K150

Str. 14-23

\section{Bibliografia}

Baumach, A., Hefermehl, H. (1990). Wechselgesetz und Scheckgesetz. München: C.H. Beck.

Czarnecki, M., Bagińska, L. (2013). Prawo wekslowe i czekowe. Komentarz. Warszawa: C.H. Beck.

Doliński, A. (1925). Polskie prawo wekslowe. Poznań: Krajowy Instytut Wydawniczy w Poznaniu.

Einert, C. (1839), Das Wechselrecht nach dem Bedürfnisse des Wechselgeschäfts im neunzehten Jahrhundert. Lipsk: F.C.W. Vogel.

Fenichel, Z. (1934). Istota zobowiązania wekslowego. Przeglą Prawa Handlowego, (5).

Furtek, M. (1999). Papiery Wartościowe. W: J. Okolski (red.), Prawo handlowe, Warszawa: KiK Konieczny i Kruszewski.

Glasner, A., Thaler, A. (1936). Prawo wekslowe i czekowe. Komentarz. Kraków: Udziałowa Spółka Wydawnicza.

Goldberger, S. (1938). Weksle zaginione. Warszawa: Drukarnia Piotr Pyz i S-ka.

Górski, A. (1925). Prawo wekslowe i czekowe. Warszawa: Nakładem Księgarni F. Hoesicka.

Grzybowski, S. (1976). Papiery wartościowe. W: W. Czachórski (red.), System Prawa Cywilnego, Prawo zobowiązań - część szczegótowa

(Tom III, część 2). Wrocław: Zakład Narodowy im. Ossolińskich.

Howorka, M. (1928). Polskie prawo wekslowe i czekowe. Poznań: Drukarnia Nakładowa J. Kawalera w Szamotułach.

Jacobi, E. (1901). Die Wertpapiere in bürgerlichen Recht. Jena: Gustav Fischer.

Janczewski, S. (1946). Prawo handlowe, wekslowe i czekowe. Warszawa: Trzaska, Evert i Michalski.

Jastrzębski, J., Kaliński, M. (2008). Prawo wekslowe i czekowe. Komentarz. Warszawa: Wydawnictwo Prawnicze LexisNexis.

Jastrzębski, R. (2003). Funkcje weksla w II Rzeczypospolitej. Warszawa: Liber.

Kaliński, M. (2000). Umowny charakter zobowiązania wekslowego, cz. I. Prawo Papierów Wartościowych, (11).

Kaliński, M. (2000). Umowny charakter zobowiązania wekslowego, cz. II. Prawo Papierów Wartościowych, (12).

Komosa, T., Opalski, W. (1997). Prawo wekslowe. Prawo czekowe. Komentarz. Warszawa: Wydawnictwo PWN. 
Koziński, M. H. (2016). Weksle. W: A. Szumański (red.), System Prawa Prywtanego. Prawo Papierów Wartościowych (Tom 18). Warszawa: C.H. Beck.

Koziński, M. H. (1999). Prawo wekslowe. Toruń: Towarzystwo Naukowe Organizacji i Kierownictwa „Dom Organizatora”.

Kuntze, J. E. (1858). Über den Verkehr mit negoziablen Creditpapiere. W: E. Siebenhaar, T. Tauchnitz (red.), Archiv für deutsches Wechselrecht (t. VIII). Lipsk: Bernhard Tauchniz.

Kuntze, J. E. (1852) Zur Charakteristik der deutschen Wechselordnung. W: E. Siebenhaar (red.), Archiv für deutsches Wechselrecht (t. II), Lipsk: Bernhard Tauchniz.

Langowski, W. (1998). Indos wekslowy. Kraków: Zakamycze.

Namitkiewicz, J. (1927). Prawo handlowe, wekslowe, czekowe i upadlościowe. Warszawa: Nakładem Księgarni F. Hoesicka.

Nazarewicz, P. (1996). Wybrane zagadnienia z zakresu prawa wekslowego, cz. I. Przeglad Prawa Handlowego, (7).

Ogiegło, L. (1995). Charakter prawny powstania zobowiązania wekslowego. Rejent, (9).

Rosenblüth, I. (1936). Prawo wekslowe i czekowe. Komentarz. Kraków: Księgarnia Powszechna.

Siebenhaar, E. (1866). Prüfung der Wechseltheorien. W: Archiv für deutsches Wechselrecht (t. XVI). Lipsk: Bernhard Tauchniz.

Siegiel, H. (1873), Das Versprechen als Verpflichtungsgrund. Berlin: Vahlen.

Słuszkiewicz, Z. (1900). Krótki wykład austryackiego prawa wekslowego wraz z Ustawa wekslowa z dnia 25. stycznia 1850 Dz. u. p. Nr. 51. Złoczów: Nakładem i drukiem Księgarni Wilhelma Zuckerkandla.

Szczygielski, A. D. (1936). Prawo wekslowe i czekowe 1936. Warszawa: Biblioteka Prawnicza.

Szpunar, A., Kaliński, M. (2003). Komentarz do prawa wekslowego i czekowego. Warszawa: LexisNexis.

Szpunar, A. (1996). Komentarz do prawa wekslowego i czekowego. Warszawa: Wydawnictwo Prawnicze.

Szpunar, A. (1992). O powstaniu zobowiązania wekslowego. Przegląd Ustawodawstwa Gospodarczego, (1).

Szpunar, A. (1991). Podstawowe problemy papierów wartościowych. Państwo i Prawo, (2).

Thöl, H. (1878). Das Handelsrecht (t. II). Das Wechselrecht. Lipsk: Fues's Verlag (R. Reisland).

Ulmer, E. (1938). Das Recht der Wertpapiere. Stuttgart-Berlin: Kohlhammer.

Volkmar, L., Löwy, S. (1857). Begriff und Charakter des Wechsels. Zeitschrift für das gesamte Handelsrecht, (2).

Volkmar, L., Löwy S. (1858), Das Wesen des Indossaments. Zeitschrift für das gesamte Handelsrecht, (3).

Wróblewski, S. (1936). Prawo Wekslowe i Czekowe. Kraków: Leon Frommer.

Zawada, K. (1990). Umowa przelewu wierzytelności. Kraków: Nakładem Uniwersytetu Jagiellońskiego. 